\title{
Antibody to hepatitis C virus in risk groups in Canada
}

\author{
RK CHAUDHARY, PHD, THERESA MO, MSC
}

\begin{abstract}
RK Chaudhary, T Mo. Antibody to hepatitis C virus in risk groups in Canada. Can J Infect Dis 1992; 3(1):27-29. The prevalence of antibodies against hepatitis $\mathrm{C}$ virus (HCV) was studied in hemophiliacs, hemodialysis patients, intravenous drug abusers, female prisoners, homosexuals, individuals with no markers of recent hepatitis A or B virus infections and normal individuals (federal public servants), by an enzyme immunoassay (Ortho Diagnostic Systems Inc). Repeat positive samples were further tested by recombinant immunoblot assay (RIBA) HCV (Chiron Corp, California). The number of samples positive for antibodies to HCV (anti-HCV) was higher with enzyme immunoassay than by RIBA HCV in most cases. A high prevalence of anti-HCV was detected in hemophiliacs by both enzyme immunoassay (68.8\%) and RIBA $\mathrm{HCV}(53.7 \%)$. Among intravenous drug abusers and female prisoners the prevalence rates for anti-HCV were $42.8 \%$ and $29.8 \%$, respectively, by RIBA HCV; the results with enzyme immunoassay were only slightly higher. The prevalence rate was also high by both tests (54.2\%) in hemodialysis patients' sera taken during 1980-82, when many cases of non-A,non-B hepatitis were suspected in this group. In contrast, only $14.1 \%$ of sera taken during 1990 were positive by RIBA HCV. In individuals with no markers of recent hepatitis A or B infections, $13.4 \%$ were positive by enzyme immunoassay, whereas only $4.5 \%$ were reactive by RIBA $\mathrm{HCV}$. The lowest prevalence was seen in homosexuals (2.3\%) and normal individuals (1.2\%) by RIBA HCV. These results indicate a high prevalence of anti-HCV in high risk groups tested in Canada.
\end{abstract}

Key Words: Enzyme immunoassay, Hepatitis C virus, Non-A,non-B hepatitis

\section{L'anticorps contre le virus de l'hépatite $\mathrm{C}$ dans les groupes à haut risque au Canada}

RESUME: La prévalence des anticorps contre le virus de l'hépatite C (anti-VHC) a été étudiée chez les hémophiles, les malades hémodialysés, les utilisateurs de drogues injectées par voie intraveineuse, les prisonnières, les homosexuels, les personnes ne présentant aucun marqueur d'infection récente par le virus de l'hépatite A ou B et les personnes normales. Les sérums ont été étudiés par un dosage immunoenzymatique (Ortho Diagnostic) et les échantillons positifs ont été confirmés par un immunoblot dénommé RIBA HCV (Chiron Corp, CA). Dans la plupart des cas, le dosage immunoenzymatique a détecté un nombre supérieur de résultats positifs. Les deux tests ont décelé une prévalence élevée d'anti-VHC chez les hémophiles (dosage immunoenzymatique 68,8 \%; RIBA VHC 53,7\%). Parmi les utilisateurs de drogues et les prisonnières, le taux de prévalence d'anti-VHC indiqué par RIBA VHC était de 42,8\% et de 29,8\% respectivement; les résultats obtenus par dosage immunoenzymatique n’étaient que légèrement supérieurs. Le taux de prévalence était également élevé $(54,2 \%)$ chez les hémodialysés dont les sérums avaient été analysés des deux façons durant 1980-82, et chez qui ont soupçonnait alors de nombreux cas d'hépatite non-A, non-B. Par contre, 14,1\% seulement des sérums prélevés au cours de 1990 se sont avérés positifs en RIBA VHC. Chez les personnes n'ayant aucun marqueur d'infection récente par le virus de l'hépatite A ou $\mathrm{B}$, les résultats étaient positifs dans $13,4 \%$ des cas par dosage immunoenzymatique et dans 4,5\% seulement par RIBA VHC. La prévalence la plus faible par RIBA VHC se trouvait parmi les homosexuels $2,3 \%$ ) et les personnes normales $(1,2 \%)$. Ces résultats indiquent une prévalence élevée d'anti-VHC dans la population à haut risque examinée au Canada.

Laboratory for Viral Hepatitis, National Laboratory for Special Pathogens, Laboratory Centre for Disease Control, Health and Welfare Canada, Ottawa, Ontario

Correspondence and reprints: Dr RK Chaudhary, Laboratory for Viral Hepatitis, Bureau of Microbiology, Laboratory Centre for

Disease Control, Ottawa, Ontario K1A OL2

Received for publication March 1, 1991. Accepted April 26, 1991 
$\mathrm{C}$ LINICAL CASES OF POST TRANSFUSION HEPATITIS WITHOUT serological evidence of infection with hepatitis A. $\mathrm{B}$, cytomegalovirus or Epstein-Barr virus, were until recently considered by exclusion to be non-A,non-B hepatitis (1). Publication of viral markers found for one of the non-A,non-B agents which has been designated hepatitis $\mathrm{C}$ virus ( $\mathrm{HCV}$ ), have changed the picture. It is now known that hepatitis $\mathrm{C}$ cases are not only associated with transfusion, but sporadic cases account for 10 to $25 \%$ of all adult hepatitis patients (2). HCV infection has also been reported in hemodialysis patients (3), drug addicts (4), hemophiliacs (5) and persons accidentally inoculated with contaminated needles. Forty to $50 \%$ of patients infected with $\mathrm{HCV}$ may become chronic carriers (6) and develop cirrhosis (7). While the ability to detect infection with HCV is encouraging, there are other transfusion-associated non-A, non-B agents which have not yet been identified.

The authors presented a Canadian perspective of the prevalence of antibodies to $\mathrm{HCV}$ (anti-HCV) in different risk groups. This is an updated version of a publication in the Canada Diseases Weekly Report (8), which includes additional data from 85 hemodialysis patients and 260 individuals with no markers of recent hepatitis A or B virus infection. It also includes results of the recombinant immunoblot assay (RIBA) HCV test.

\section{MATERIALS AND METHODS}

An enzyme immunoassay test is now commercially available (Ortho Diagnostic Systems Inc) for the detection of anti-HCV. The validity of the test based on HCV protein cloned in yeast cells was established by examining well documented test panels of sera from both patients with non-A,non-B post transfusion hepatitis and implicated blood donors (9).

Serum specimens from hemophiliacs, intravenous drug abusers, female prisoners, homosexuals, hemodialysis patients in 1980-82, hemodialysis patients in 1990, suspected hepatitis patients (negative for markers of recent hepatitis $\mathrm{A}$ or $\mathrm{B}$ virus infection), and normal individuals were tested for anti-HCV. Sera from federal public servants were tested as normal controls. These sera were obtained from the Medical Services Clinic in Ottawa where public servants are given their routine annual medical examinations. The sources of samples tested are given in Table 1. A large number of female prisoners had a history of intravenous drug abuse but the authors were unable to obtain an accurate number. None of the patients without hepatitis $A$ or $B$ virus infection had been recently transfused. The sera from hemophiliacs, intravenous drug abusers, female prisoners and homosexuals were kindly provided by Dr M O'Shaughnessy of the Federal Centre for AIDS. The sera from the hemodialysis patients taken during 1980-82 and 1990 were provided by Dr G Posen of the Ottawa Civic Hospital.

Samples were tested by enzyme immunoassay and those positive were repeat tested. The recommended protocol was followed for setting up the test. The enzyme immunoassay repeat positive samples were further tested by the RIBA HCV supplementary test (Chiron Corp, California) for confirmation. The RIBA HCV test is an immunoblot test in which protein antigens C100-3 and 5-1-1 are immobilized as individual bands on nitrocellulose strips along with two levels of positive controls and a band for human superoxide dismutase. The kit protocol for performing the test was followed.

\section{RESULTS}

The results showed that $68.8 \%$ of the hemophiliacs were positive for anti-HCV by enzyme immunoassay but only $53.7 \%$ were confirmed by RIBA HCV (Table 1). This showed a high prevalence of anti-HCV in Canadian hemophiliac patients. The prevalence was also high (54.2\%) among the hemodialysis patients (1980-82), and test results by enzyme immunoassay and RIBA HCV were the same. Only $14.1 \%$ of hemodialysis patients were positive for anti-HCV by RIBA HCV during 1990 Canadian intravenous drug abusers and female prisoners had a prevalence rate of $42.8 \%$ and $29.8 \%$. respectively, by RIBA HCV. The prevalence by enzyme immunoassay was slightly higher. The prevalence rate

TABLE 1

Results of testing for antibody to hepatitis $\mathrm{C}$ virus (anti-HCV) in risk groups

\begin{tabular}{|c|c|c|c|c|c|c|c|}
\hline \multirow{2}{*}{\multicolumn{2}{|c|}{$\begin{array}{l}\text { Group tested } \\
\text { Hemophiliacs }\end{array}$}} & \multirow{2}{*}{$\begin{array}{c}\text { Number } \\
\text { tested } \\
93\end{array}$} & \multicolumn{2}{|c|}{$\begin{array}{c}\text { Number anti-HCV repeat } \\
\text { positive by EIA (\%) }\end{array}$} & \multicolumn{2}{|c|}{$\begin{array}{l}\text { Number anti-HCV posi- } \\
\text { tive by RIBA HCV (\%) }\end{array}$} & \multirow{2}{*}{$\begin{array}{l}\text { Source } \\
\text { Montreal }\end{array}$} \\
\hline & & & 64 & $(68.8)$ & 50 & $(53.7)$ & \\
\hline \multirow[t]{2}{*}{ Hemodialysis patients } & $1980-82$ & 24 & 13 & $(54.2)$ & 13 & $(54.2)$ & Civic Hospital, Ottawa \\
\hline & 1990 & 85 & 15 & $(17.6)$ & 12 & $(14.1)$ & \\
\hline \multicolumn{2}{|c|}{ Intravenous drug abusers } & 42 & 19 & $(45.2)$ & 18 & $(42.8)$ & $\begin{array}{l}\text { Toronto, Calgary, Ottawa, British } \\
\text { Columbia }\end{array}$ \\
\hline \multicolumn{2}{|l|}{ Female prisoners } & 77 & 24 & $(31.2)$ & 23 & $(29.8)$ & $\begin{array}{l}\text { Tanguay Prison, Montreal; history } \\
\text { of intravenous drug abuse }\end{array}$ \\
\hline \multicolumn{2}{|l|}{ Homosexuals } & 86 & 3 & $(3.5)$ & 2 & $(2.3)$ & Vancouver \\
\hline \multicolumn{2}{|c|}{ Sera negative for $\mathrm{HAV}$ and $\mathrm{HBV}^{*}$} & 335 & 45 & $(13.4)$ & 15 & $(4.5)$ & Eastern provinces and Quebec \\
\hline \multicolumn{2}{|l|}{ Normal individuals } & 256 & 5 & $(2.0)$ & 3 & $(1.2)$ & $\begin{array}{l}\text { Federal public servants (Ottawa) } \\
\text { routine annual check-up }\end{array}$ \\
\hline
\end{tabular}

"Sera from individuals with no markers of recent hepatitis A virus (HAV) or hepatitis B virus (HBV) infections. ElA Enzyme immunoassay 
for anti-HCV was low (2.3\%) in homosexuals by RIBA $\mathrm{HCV}$. Among individuals with no markers of recent hepatitis $\mathrm{A}$ or $\mathrm{B}$ virus infections, the prevalence of anti-HCV was $13.4 \%$ by enzyme immunoassay and $4.5 \%$ by RIBA HCV. Sera from normal individuals (federal public servants) showed a low prevalence of anti-HCV by both enzyme immunoassay $(2.0 \%)$ and RIBA HCV (1.2\%).

\section{DISCUSSION}

The results showed a high prevalence (53.7\%) of anti-HCV in Canadian hemophiliac patients, similar to findings previously reported from Germany and Spain (10,11). It was also observed that only $78 \%$ of samples positive by enzyme immunoassay were confirmed by RIBA HCV. Among the hemodialysis patients (1980-82), a high prevalence of anti-HCV was detected by both enzyme immunoassay and RIBA HCV. This group had experienced many cases of non-A, non-B hepatitis, diagnosed by exclusion between 1980 and 1982. This explains the reason for a prevalence rate in this group higher than rates reported from other centres $(10,11)$. In Germany and Spain (10,11), 5.5\% and 20\% of hemodialysis patients, respectively, were positive for antiHCV, whereas in Japan $18.7 \%$ were reported (12) to be positive for anti-HCV by enzyme immunoassay. On the other hand, only $14.1 \%$ of hemodialysis patients were positive for anti-HCV by RIBA HCV in 1990, similar to rates reported from other centres. This difference could be explained by the fact that non-A,non-B activity was low during 1990. Canadian intravenous drug abusers and female prisoners had a high prevalence of anti-HCV by RIBA HCV. Although the numbers were small, these rates may be indications of cases in general. The prevalence of anti-HCV in intravenous drug abusers in Canada was similar to those reported from Austria (50\%) (13). The present authors are the first to report a high prevalence of anti-HCV in female prisoners. Indications are that the female prisoners were intravenous drug abusers before incarceration.

The prevalence rate for anti-HCV was low (2.3\%) in homosexuals, similar to rates reported from Denmark (4.1\%) (14), although a somewhat higher prevalence rate $(8 \%)$ was reported from Spain (11). Four and onehalf per cent of the sera tested from individuals with no markers of recent hepatitis A or B virus infection were positive for anti-HCV by RIBA HCV. Also in this group, only $33.3 \%$ of enzyme immunoassay positive samples were confirmed by RIBA HCV. This shows the weakness of enzyme immunoassay for testing samples from low risk groups. In contrast, in a random serum set from normal individuals (federal public servants), only $1.2 \%$ of sera tested were positive for anti-HCV by RIBA HCV. In the Canadian blood donor population only $0.39 \%$ were positive for anti-HCV by enzyme immunoassay (personal communication).

These results show that $\mathrm{HCV}$ is an important cause of hepatitis; particularly high rates were found among hemophiliacs, intravenous drug abusers, female prisoners and hemodialysis patients, indicating the importance of parenteral transmission. On the other hand, a lower prevalence rate $(2.3 \%)$ among homosexuals indicated that HCV is not readily transmitted by the sexual route, although occasional infection may occur. All results were confirmed by an immunoblot test (RIBA $\mathrm{HCV}$ ) with the finding that in low risk groups a supplementary test is essential.

ACKNOWLEDGEMENTS: We express our appreciation and thanks to Dr MV O'Shaughnessy and Mrs D Lepine for kindly providing the samples from high risk groups. I also thank Dr K Rozee for editing the manuscript. We also thank Mrs Sylvia Frenette for technical assistance and Mrs Marina Kanabe for secretarial help.

\section{REFERENCES}

1. Feinstone SM, Kapikian AZ, Purcell RH, Alter HJ, Holland PV. Transfusion-associated hepatitis not due to viral hepatitis type A or B. N Engl J Med 1975;292:767-70.

2. Alter MJ, Gerety RJ, Smallwood LA, et al. Sporadic non-A, non-B hepatitis: Frequency and epidemiology in an urban US population. J Infect Dis 1982;145:886-93.

3. Galbraith RM, Portman B, Eddleston ALWF, Williams R, Gower PE. Chronic liver disease developing after outbreak of HBs-negative hepatitis in haemodialysis unit. Lancet 1975;ii:886-90.

4. Moshey JW, Redeker AG, Feinstone SM, Purcell RH. Multiple hepatitis viruses in multiple attacks of acute viral hepatitis. N Engl J Med 1977;296:75-8.

5. Fletcher ML, Trowell JM, Craske J. Non-A, non-B hepatitis after transfusion of factor VIII in infrequently treated patients. Br J Med 1983;287:1754-7.

6. Alter $\mathrm{HJ}$. Chronic consequences of non- $\mathrm{A}$, non-B hepatitis. In: Seeff LB, Lewis JH, eds. Current Perspectives in Hepatology. New York: Plenum Medical Book Co, 1989:83-97.

7. Okuda H, Obata H, Motoike Y, et al. Clinical pathological factors of hepatocellular carcinoma - Comparison of hepatitis B seropositive and seronegative patients. Hepatogastroenterology 1984:31:64-8.

8. Chaudhary R, Mo T. Antibody to hepatitis C virus in risk groups in Canada. Can Dis Weekly Rep 1990:16(5):23-5.

9. Kuo G, Choo QL, Alter HJ, et al. An assay for circulating antibodies to a major etiologic virus of human non-A. non-B hepatitis. Science 1989;244:362-4.

10. Roggendorf M, Deinhardt F, Rasshofer R, et al. Antibodies to hepatitis C virus. Lancet 1989;ii:324-5.

11. Esteban JI, Esteban R, Viladomiu L, et al. Hepatitis C virus antibodies among risk groups in Spain. Lancet 1989;ii:294-6.

12. Tamura I, Kobayashi Y, Koda T, et al. T. Hepatitis C antibodies in haemodiaylsis patients. Lancet 1990;335:1409.

13. Hue Mer HP, Prodinger W, Larcher C, Most J, Dierich MP. Correlation of hepatitis C virus antibodies with HIV-1 seropositivity in intravenous drug addicts. Infection 1990;18:122.

14. Melbye M, Biggar RJ, Wantzin P, Krogsgaard K, Ebbesen P, Becker NG. Sexual transmission of hepatitis C virus: Cohort study (1981-9) among European homosexual men. Br J Med 1990;301:201-12. 


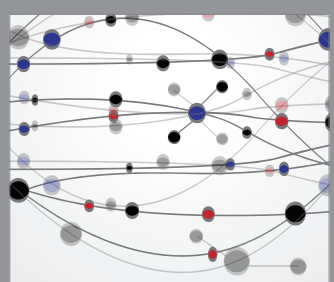

The Scientific World Journal
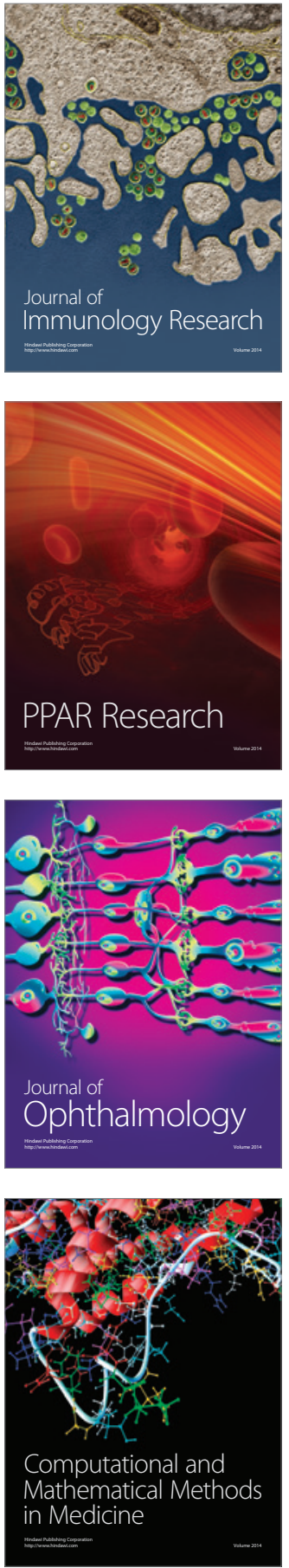

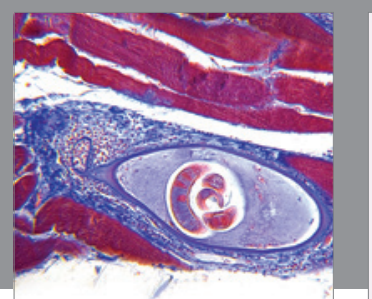

Gastroenterology Research and Practice

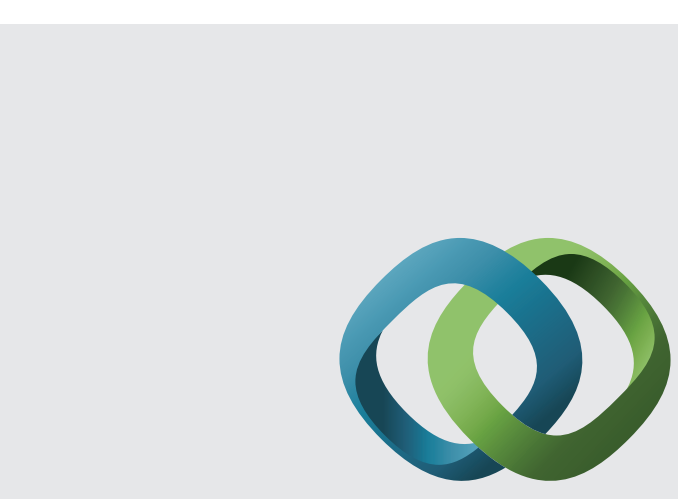

\section{Hindawi}

Submit your manuscripts at

http://www.hindawi.com
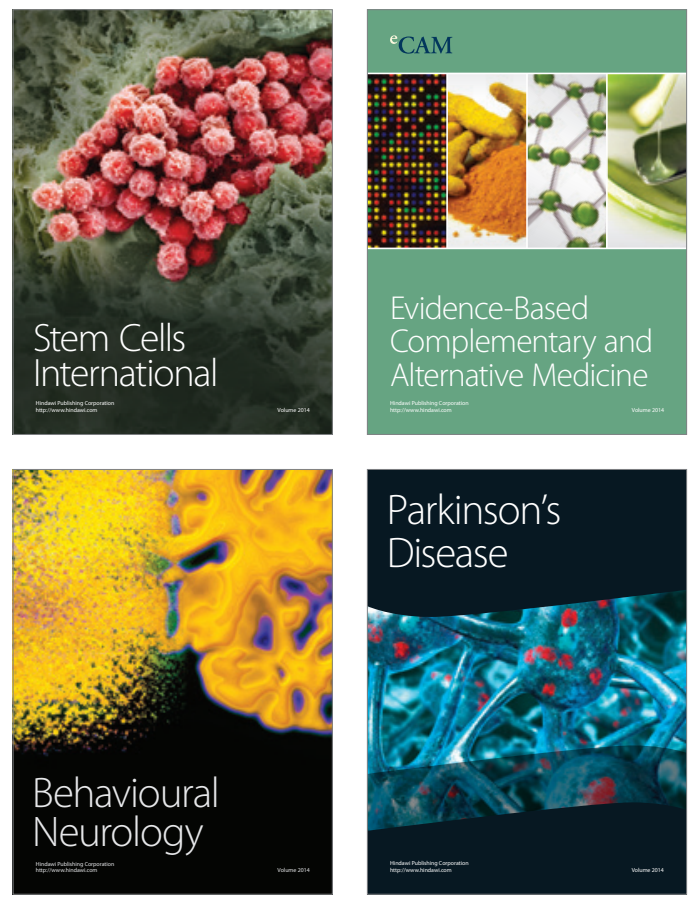
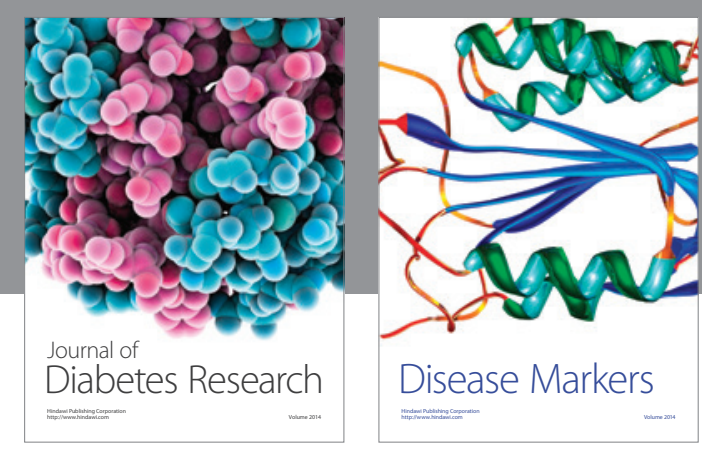

Disease Markers
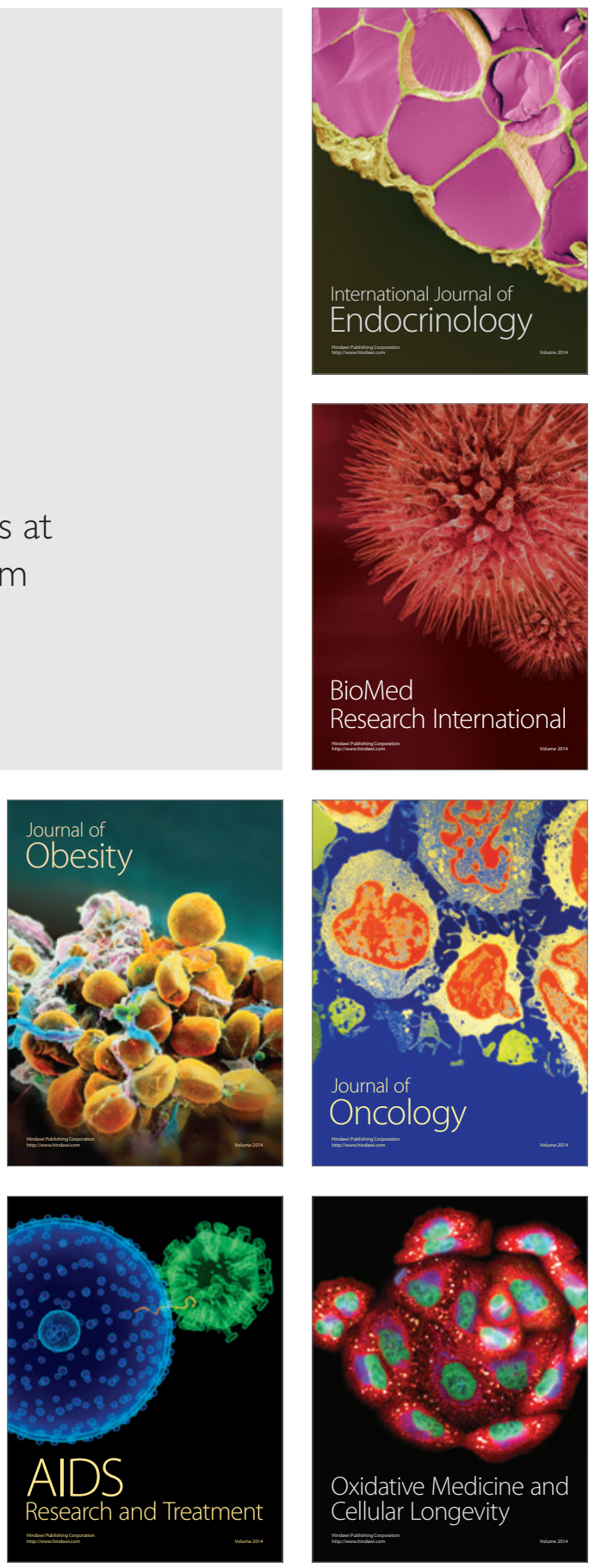